\title{
The Pleasures and Pitfalls of Naming in Vladimir Nabokov's Stories
}

\author{
Nassim W. Balestrini \\ Johannes Gutenberg Universität
}

\begin{abstract}
True to his aesthetic principles, Nabokov expresses his love for detail in imaginative naming strategies. The conspicuous absence of names as well as the deliberate use of multilingual names constitute an important facet of his short fiction. Nabokov challenges the reader to differentiate between names that evoke stereotypes and names whose etymology assumes significance, between the purposes of supposedly real names and of appellations admittedly invented by a secretive or ironic narrator. Names as aesthetic entities invite scrutiny of their sounds, their printed shapes, their associations with colors, with plants or other phenomena. As the examples will illustrate, the impact of names in Nabokov's stories ranges from comic or tragic effects to intricate patterns of interrelated meanings.
\end{abstract}

Acts of naming and particular names themselves reflect Nabokov's aesthetics in which nothing is arbitrary. Critics have commented on names in the Russian-American writer's novels, but his short fiction has not been systematically analyzed in that respect. The following discussion of names in selected stories thus contributes to filling this gap. ${ }^{1}$ Nabokov's various strategies of excluding or including names challenge the reader to discern minute details as well as complex patterns through which a story becomes an entity worth exploring as an individual aesthetic construct.

\section{Nabokov's Aesthetics}

Critics have held various opinions on Nabokov as either an aesthete in favor of art for art's sake or a writer with a clear sense of ethics. Attitudes towards the balance or imbalance between Nabokov's aesthetics and ethics have ranged from condemning him as a heartless virtuoso writer to praising him as a writer with unwavering moral convictions. ${ }^{2}$ In the theoretical lectures published along with his more

Names 50.1 (March 2002):23-42

ISSN:0027-7738

(1) 2002 by The American Name Society 


\section{Names 50.1 (March 2002)}

concrete lectures on European literature, Nabokov expresses his views on art, science, and what he considers ideal reactions to both. The artist as well as the scientist and the reader must, first of all, be individuals who find the delicate balance between cerebral rationality and spiritual logic. For instance, Nabokov rejects "commonsense" (which he spells as one word) because it replaces individual sense perception with generalized experience. "Commonsense" also fosters the belief in human depravity, while "the irrational belief in the goodness of man" (Nabokov 1980 , 373) can only be confirmed "within the emphatically and unshakably illogical world which I am advertising as a home for the spirit." Similarly, while common sense abounds in generalities, Nabokov promotes "the supremacy of the detail over the general" (373).

Details, then, occupy both the reader and the writer. For the writer, "the work of art is invariably the creation of a new world" (Nabokov $1980,1)$, whose "details" the reader must "notice and fondle." While the focus on details may already hint at the role of names, Nabokov more concretely describes the writer as creating his new world and then being "the first man to map it and to name the natural objects it contains" (2). The reader is called upon to examine this world with all its appellations and particulars, in order to reach the same spiritual and intellectual heights that the writer attained. In this process, the reader must use "imagination $[,] \ldots$ memory $[,] \ldots$ a dictionary $[,] \ldots$ [and] some artistic sense" (3). With these tools, "the reader enters into the spirit of the game" and sets out to "enjoy-passionately enjoy, enjoy with tears and shivers-the inner weave of a given masterpiece" (4). Ultimately, the reader should experience "an artist's passion and a scientist's patience" (5), two interchangeable experiences to the writer and entomologist Nabokov who, at the end of his lecture, describes a good-quality novel as "a merging of the precision of poetry and the intuition of science" (6). Neither the writer nor the reader can ignore details, but must rather toy with the intellectual and aesthetic potentials of seeming trifles in order to discern their meaning in light of their structural arrangement. ${ }^{3}$

In short, one may describe Nabokov's aesthetics as enjoying the plasticity of detail in its mixture of concreteness and deception as perceived by one's senses and absorbed into one's consciousness. Ultimately, conscious and devoted attention to ostensibly frivolous minutiae expresses belief in a beneficent power behind creation and openness towards its potential to inspire the individual artist, scientist, and recipient of artistic and scientific creations. 


\section{Nabokov's Use(s) of Names: A General Introduction}

Nabokov's references to his actual name and to his pen name of the 1920s and 1930s stress the playful and multi-dimensional role of names. In numerous novels, stories, interviews, and essays, Nabokov incorporates anagrams or other allusions to his name. For instance, when asked about his "social circle," he includes a "Mr. Vivian Badlook" (Nabokov $1973,110)$. Other anagrams of his name are ". . . Vivian Darkbloom, Vivian Bloodmark, . . . the exotic Blavdak Vinomori, . . Baron Klim Avidov" as well as "Adam von Librikov" (Johnson 1979, 407). ${ }^{4}$ Nabokov illustrates his pen name, Sirin, which he originally used in order not to be confused with his father Vladimir Dmitrievich Nabokov, in a 1971 interview: "In modern times sirin is one of the popular Russian names of the Snowy Owl, the terror of tundra rodents, and is also applied to the handsome Hawk Owl, but in old Russian mythology it is a multicolored bird, with a woman's face and bust, no doubt identical with the 'siren,' a Greek deity, transporter of souls and teaser of sailors" (Nabokov 1973, 161)..$^{5}$ The writer also explains the connection between Sirin and the Russian symbolist movement (161) which influenced his early poetry. ${ }^{6}$

Nabokov's selection of a pen name with mythical, literary, and ornithological meanings recalls the close relationship between art and science in his works. The act of naming, already described in the context of creating fictional worlds, also fascinates the lepidopterist Nabokov who defines as one of the highlights of his life "the capture of an undescribed butterfly" $(1973,133) .{ }^{7}$ Accordingly, he concludes his volume of interviews and essays with scientific publications on the socalled "Nabokov's Blue" butterfly and with reviews of butterfly-related publications (315-35). ${ }^{8}$ In one of these papers, he defines the function of scientific appellations as "express[ing] structural affinities and divergences" (320). The attention to details, to deceptive similarity and covert difference, and to structure again recalls Nabokov's attitude towards the study of literature as "a kind of detective investigation of the mystery of literary structures." 9

Just as much as a scientist does not leave the naming of specific phenomena to coincidence, the artist selects names with a specific purpose in mind. ${ }^{10}$ Nabokov's detailed explanation of the sounds and meanings in the name Lolita serves as a case in point for specificity and delight in naming. He stresses the "lyrical lilt" $(1973,25)$ of the doubled "limpid and luminous" 1 -sound in the "diminutive" that goes 


\section{Names 50.1 (March 2002)}

along nicely with the "Latin tenderness" of the "suffix '-ita." The "source name" Dolores evokes "roses and tears" which imply Lolita's "heartrending fate." The more common diminutive "Dolly"11 suits her surname "Haze" in which her Irish background and the German word for hare-Hase-merge. Nabokov's careful translations of character names or their replacement with a functional equivalent also prove the importance he attached to names. The variety and depth of his uses of names show their correspondence with and intricate role in his overall aesthetics.

\section{Unnamed Characters}

Eight of the sixty-five stories Nabokov wrote between the early 1920 s and the late $1950 \mathrm{~s}^{12}$ do not include any personal names for the narrator and the characters. Six stories feature an unnamed loved one, ${ }^{13}$ and in four out of these six stories, the unnamed loved one is deceased. ${ }^{14}$ In these works, the reader must find clues to characterizations in motifs such as color, light, and shadow, sounds and smells, or the presentation of recollections. Refraining from mentioning a loved one's name may express reverence for the deceased one's soul which has been freed from the earthly realm in which mortal beings rely on naming people and things. ${ }^{16}$ At the same time, Nabokov indicates the affect of hearing a name without seeing its bearer. In the story "Beneficence" (1924) (7478), the narrator waits in vain for his nameless "deceitful" (74) lover, all the while expecting that she will not come: "Here is the kind of feeling I would experience whenever your name was mentioned in my presence: a bolt of black, a scented, forceful motion-that's how you threw back your arms when adjusting your veil" (74). In the same vein, he associates her with "warm black silk" (74), visualizes "her seal-fur coat and the black lace hanging from [her] hat brim" (76), and remembers the "fleeting shadow of [her] voice" (77). ${ }^{17}$ In "Russian Spoken Here" (1923) (6-13), an anonymous enemy represents a whole group of people: a Russian émigré family "imprisons" a Soviet secret police agent in their large bathroom; ironically, the unnamed spy rather enjoys the room service in his not so uncomfortable cell.

\section{Stereotyping Through Names}

In the first two of the following examples, barbaric Nazi-type characters receive names which primarily stereotype them as primitive brutes; the second set of stories, however, includes names which 
confirm such a characterization on a deeper level. A comparatively harmless German specimen appears in "Details of a Sunset" (1924) (7985). The protagonist Mark Standfuss's friend, "jolly Adolf," expresses his jolliness by the stereotypically rough, masculine act of "pok[ing] hi[s friend] in the ribs" - but his gesture loses its harmlessness by reminding Mark of the previous night's torturous nightmare in which his late father "began to tickle him silently, violently, and relentlessly" (81). "Crewcut Adolf . . . propping himself on his cane as if it were a tail . .." (82) assumes animalistic features when he persuades Mark to go and have a drink, a circumstance that prevents Mark from finding out about his fiancée's decision to break up with him and thus implicitly leads to his death which occurs on the way to her house.

While the name Adolf probably does not hint specifically at Hitler in this 1924 story, ${ }^{18}$ Nabokov confirms that in "The Leonardo" (1933) (354-63) the two brothers named Gustav and Anton who murder an unfathomable and-to them-consequently dangerous foreigner named Romantovski were contemporaneous with "Hitler's grotesque and ferocious shadow [which was] falling on Germany at the time" (649). But Nabokov does not simply juxtapose two German brutes with an enigmatic, and thus seemingly "romantic," Pole who threatens to disturb the brothers' simple world of "every man shall sweat, every man shall eat" (355). The primitively physical, two-dimensional world of people with names comprising two syllables (including Gustav's fiancée Anna) consists of characters without individuality or spiritual depth. Consequently, the narrator reduces Gustav and Anton to their red and gray sweaters, describes them as "becoming identical twins" (357), and-perceived through Romantovski's fear-as expanding into a nameless, "Gigantic" (357), monstrous presence. They "form a crowd" (358) and eventually become bloodthirsty murderers. However, the foursyllable Romantovski does not turn out to be, as the narrator supposedly thought, "a remarkable poet whom poverty obliged to dwell in that sinister district" (363), but a counterfeiter whose death the police will probably attribute to competitors in his illegal business. Nonetheless, the dissolution of Romantovski's erroneous image and of the fictional world at the end of the story leaves the narrator-writer's values of a tenderly imaginative perspective on the world and of the search for "Harmony and meaning" (363) intact. Apparently, names may be deceptive and/or prophetic. 


\section{Names 50.1 (March 2002)}

The second group of names, namely those that go beyond merely evoking a stereotyped atmosphere set in a specific cultural and historical context, comprises unambiguous stereotypical names whose meaning and etymology imply the vicious consequences of an anti-individualistic crowd mentality, as found in "Cloud, Castle, Lake" (1937) (426-33) and "Conversation Piece, 1945" (583-93). ${ }^{19}$ In the first narrative, the Russian émigré Vasiliy Ivanovich has won a pleasure trip during which his German companions continuously punish him for being different. The narrator indicates the violent tormentors' interchangeability by giving them either identical first or last names, ${ }^{20}$ or names with the same opening sound as in "Schultz" and "Schramm" (427, 429). Adding to their snake-like hissing, "Schultz" and "Schramm" connote violence and the assertion of authority. "Schultz" evokes the sound of "Schuld" ("guilt"/"debt"), ${ }^{21}$ and, by implication, the two Schultzes 'collect' Vasiliy Ivanovich's 'debt' in terms of enforcing a predetermined form of enjoyment-a debt ironically incurred by winning a prize. Also playing with sound, the name "Schramm" is a "metonymic nickname for a person with a prominent scar, from Ger. Schramme, Yid. shram scar . . ."22 Interestingly, the image of a prominent facial scar recalls stereotypical German fraternity men of that era, as found in Heinrich Mann's novel Der Untertan (alternately translated as The Straw Man or The Loyal Subject) which implicitly illustrates the genesis of the cowardly and violently inclined protagonist's fascist persuasion.

In contrast to these names with rather clear implications for a reader familiar with German vocabulary, Nabokov's "Conversation Piece, 1945 " indulges in the ambiguities of real or invented names which contribute to the convoluted plot of mistaken identities. Mrs. Sybil Hall, a middle-aged American woman, invites the unnamed first-person narrator to a party because her friend Mrs. Sharp had recommended she should do so. Not only is the narrator's acquaintance Mrs. Sharp not identical with Mrs. Hall's eponymous friend, but the latter Mrs. Sharp intended to invite not the narrator, but his "disreputable namesake, complete from nickname to surname, a man whom I have never seen in the flesh but whose vulgar personality I have been able to deduce from his chance intrusions into the castle of my life" $(583) .{ }^{23}$ During the horrible gathering, several American women court a dubious German immigrant who dissolves German guilt by characterizing Hitler as a foreign lunatic and all Germans as good-hearted dreamers. Expressing his disgust toward these dangerous half-educated anti-Semites, the narrator gives them telling names. ${ }^{24}$ 
Like Schultz and Schramm, Sybil, ${ }^{25}$ Mrs. Sharp, and the guest of honor Dr. Shoe bear names commencing with hissing sibilants. The combination between the pagan prophetess Sybil ${ }^{26}$ and the old and very common last name Hall might ironically comment on the narrator's initial lack of suspicion and at the prevalence of Sybil Hall's prejudices. In the same vein, the doubled Mrs. Sharp contradicts the keenness implied in her last name. ${ }^{27}$ The narrator describes the man he calls Dr. Shoe in terms of stereotypical associations with snakes: Dr. Shoe strikes him as a rather ugly and not too well-groomed weakling whose "limp and moist" (585) hands and hypnotically half-closed eyes rimmed with equally deceptive soft lashes (586) fill the narrator with disgust. ${ }^{28} \mathrm{Dr}$. Shoe's name may also imply the narrator's experience of attending the party in his namesake's shoes. These symbolical shoes filled with a different person's feet find their humorous counterpart in Dr. Shoe's hat with which the narrator accidentally leaves the party. Possibly indicating his ideological crusade, Dr. Shoe's fedora stems from "Werner Bros. Chicago" (591), "Werner" being an "old Germanic personal name composed of the tribal name Warin + the element heri, hari [meaning] army, warrior." Just as Schultz and Schramm phonetically recall "Schuld" and "Schramme," the audible echo of "Wehr-" (as in "Wehrmacht") in "Werner" supports the etymological explanation. ${ }^{29}$

While wearing another man's hat and being in another man's shoes makes the narrator assert his own individuality, he denies the undeserving party guests any individuality whatsoever by admittedly ${ }^{30}$ giving them fictitious appellations based on their looks or behavior: "a fat little lady" becomes "Mrs. Mulberry" (585), and she assumes this identity by calling her anti-Semitic husband "Mr. Mulberry" (589). "Two willowy, interchangeable maiden ladies . . had names beginning with W" (587) and, having reappeared as "the Misses W.," one of them proves to be fittingly "witty" (588; bold print added). A "Colonel Malikov or Melnikov" whose name the unobservant Mrs. Hall pronounces like "Milwaukee" (587) is "as bald as a bowling ball" (591). In addition to the narrator's delight in the triple alliterations on the person's possible names and in the description of his head, ${ }^{31}$ the Russian guest's names allow a varied play of allusions. "Melnikov" is derived "from the occupational term melnik [for] miller." The miller may have come to mind because the man made "a leathery, creaking sound, as if he wore a harness" (587), reminiscent of a horse turning the millstone. The horse reappears as its homophone in Melnikov's “hoarse Russian 


\section{Names 50.1 (March 2002)}

whisper" (587). ${ }^{32}$ "Melnikov" also evokes the verb "mel'kat" whose meaning - "to loom up indistinctly or be glimpsed fleetingly"-resembles the narrator's brief and unclear impression of the man. The name "Malikov" recalls the adjective "malyj," small, as well as the word "malik"," referring to a trail made in snow or sand. ${ }^{33}$ The narrator possibly wants the reader to consider the bowling-ball size of Malikov's head or wonder about Dr. Shoe's footprints in Malikov's mind.

While the narrator invites the reader to fathom the murky deeps of invented names, he himself remains nameless. The character differences between him and his namesake indicate the arbitrary relationship between name and character. At the same time, consciously assigned names indicate a writer's agenda and prod the reader to use "imagination," "memory," "artistic sense," and "a dictionary" (see Nabokov 1980, 3 and above). Interestingly, "Conversation Piece, 1945" contrasts with earlier stories such as "Sounds" (1923) (14-24) and "Recruiting" (1935) (397-401) whose narrators relish imagining themselves within a person's soul or consciousness or even within the being of objects. The narrator of "Sounds" experiments mentally with perceiving everything from different angles (19). In "Recruiting," the narrator tells the story of Vasiliy Ivanovich,,$^{34}$ the man sitting next to him on a park bench, but then admits that he invented his life story, thoughts, and name. Explaining the choice of name, he argues: "Well, because that blend of name and patronymic is like an armchair, and he was broad and soft, with a large cozy face, and sat, with his hands resting on his cane, comfortably and motionlessly . . " (400).$^{35}$ Possibly, the armchair is meant to be deceptively ambiguous by indicating the artist's comfort which may be conducive to creative efforts but, at the same time, may lull him into laziness. In contrast to the seemingly comfortable writer who snugly fits into his 'recruit,' the 'real-life' encounter in "Conversation Piece, 1945" illustrates a narrator's horrible confrontation with grotesque figures whose fictitious names breathe disgust and ridicule rather than the desire to nestle in them.

The Constituent Parts of Names and Their Aesthetic Arrangement: Reciprocal Palindromes

Nabokov's attention to minute details such as individual letters within names surfaces in his use of palindromes, anagrams, puns, and acrostics. I will here focus on the most frequently occurring reciprocal palindrome, i.e., the name "Otto," whose differing uses prove that the 
reader must interpret every singly or repeatedly occurring name in the context of each individual work. ${ }^{36}$

The 1925 story "A Guide to Berlin" (155-60) presents the aesthetic appeal of the mirroring in the name "Otto." Seeing the name written into a "strip of virgin snow" on "a gigantic black pipe" (155), ${ }^{37}$ the narrator rejoices in "how beautifully that name, with its two soft $o$ 's flanking the pair of gentle consonants, suited the silent layer of snow upon that pipe with its two orifices and its tacit tunnel" (155-56).$^{38}$ The two "O's" do not only imitate the pipe openings, but "Otto" is also "anagrammatically incorporated . . . into [the narrator's] description" (Johnson 1979a, 410) of the "two orifices" and the alliterating "tacit tunnel." Furthermore, based on his faculty of colored hearing, Nabokov associates the letter "o" with snowy whiteness (410) and with the iconic image of an "ivory-backed hand mirror" (403) which repeats whiteness and stresses the role of mirroring. ${ }^{39}$

A reader aware of Nabokov's predilection for mirror reflections and for symmetry will find that Nabokov transformed a nearly palindromic German surname in the 1926 Russian story "Skazka" into a French surname that invites anagrammatic readings in the English translation entitled "A Nursery Tale" (161-72). Sitting at a sidewalk coffee shop table, the protagonist, Erwin, stares at female passers-by while "the café phonograph [is] singing the Flower Aria from Faust" (162). Suddenly, a female incarnation of the devil appears and offers Erwin a deal: if he can visually collect a harem consisting of an uneven number of women by midnight, they will all be his (164). In the Russian original, the shedevil's name is "Frau Ott," an incomplete Ott-o as well as an anagram of "tot," the German word for "dead." 40 Contrasting with the aesthetically pleasing symmetry and openness of "Otto," in the anagram "tot" the two " $t$ 's" claustrophobically enclose the single "o." ${ }^{41}$ In the English translation, the devil is "a German-born woman whose last husband . . . was of French extraction, a Professor Monde" (163). "Monde" is an anagram of "demon." Pronounced with a heavy German accent, it sounds like "Mond," German for "moon," whose shape recalls the ivory-backed hand mirror. 42 "Monde" in its French meaning of "world" may allude to the depravity of the material world as depicted in Gounod's aforementioned opera Faust based on Goethe's eponymous drama. As the missing "o" of Ott may have foreshadowed, Erwin bungles his search by selecting as the thirteenth lover the same woman he had first picked hours ago, thus missing the requisite uneven 


\section{Names 50.1 (March 2002)}

number. ${ }^{43}$ Adding another irony, the protagonist's name provides more than just a German flavor. Derived "from an old Germanic personal name, composed of the elements éra honour, respect + win friend," Erwin's name contrasts with his inclinations. Although Nabokov may not have considered the name's etymology, he may well have seen "Er" ("he") and "win" (as in "to win"), thus also contrasting the implication of seeming success with the character's dismal experience.

Black and White Patterns Underneath the Surface of Names: "Breaking the News"

Stressing Nabokov's interest in structural unity, the characters in "Breaking the News" (1935) (386-91) bear names whose etymology and cultural context create a coherent network. First of all, the names identify the émigré characters not merely as generic Russians, but more specifically as Russian-speaking Jews. Secondly, several names contribute to the story's "inner weave" by reflecting the dominance of black complemented by some white in the characterization of the protagonist's world. For the near-deaf Evgeniya Isakovna Mints, the audible world wavers between complete silence without her hearing aid and crashing noise when using the device. Although her friends gather in her boarding-house room to give her the devastating news of her son's death in the black encasement of an elevator shaft, the story ends with them decidedly avoiding the reach of her hearing aid.

Evgeniya Isakovna's patronymic indicates her Jewish background, and the originally Greek male version of her first name became popular in Russia through a fourth-century missionary and, more importantly, through Pushkin's novel in verse Evgeniy Onegin. Implicitly praising the protagonist, the Greek name stems from eugenēs, meaning "well-born, noble." The last name Mints (which Nabokov only adds in the English version) is a Jewish, or-more specifically-an Ashkenazic form of the English occupational name "Minter," the German "Münzer," and the Yiddish "mintser."

Mrs. Mints's friends share her Jewish-Russian background. The Lipshteyns' name incorporates a variant of the Yiddish morpheme "lib" which means "dear." Ida Samojlovna's first husband was Vladimir Markovich Vilner, whose surname stems from the name for residents of Vilnius, Lithuania, as derived from the Yiddish word "vilner." ${ }^{44}$ Maria Osipovna's or Miss Osipov's patronymic is derived from a Russian pet form of the Biblical name Joseph. 
The Chernobylskis, who are in charge of telling Mrs. Mints about her son's death, also bear a surname associated with Russian-speaking Jews (see Hanks and Hodges 1988, "Chernyakov"). Derived from the patronymic "Chernyakov" which stems "from the nickname Chernyak [meaning] 'Black(-haired)' or 'Dark(-skinned) one'," the compound "Czernobilski" means "black-white." If one takes "Chernobylski" - with " $y$ " in place of the first " $i$ " - as a variant spelling of the previous name, then the couple fits into the black-and-white pattern of the story in which black clearly dominates. The story opens with the statement: "Eugenia Isakovna Mints was an elderly émigré widow, who always wore black" (386). As if striving to prove the correctness of the first sentence, the narrator mentions her "black woolen shawl" (386), "black net bag, handbag, and umbrella" (387), "black stockings" (387), black coat (388), black gloves (389); and even her hearing aid resembles "a small black handbag" (386). Furthermore, she is decidedly proud of the way she makes her black coffee. However, she detests her arrogant landlady "Frau Doktor Schwartz" (386)-whose name means "black" ("schwarz") in German and thus lacks the white element of Chernobylski. The presumably white, yet "yokelike" (387) collar of Mr. Chernobylski's black suit reverses the traditionally positive symbolism of white. Significantly, Mr. Chernobylski's collar rests on a chair, thus stressing the blackness of the desperate man's clothing and foreshadowing the consistent avoidance of the chokingly bitter task.

Scientifically inclined dictionary users will enjoy transcending the denotative meanings of names and their roots by contemplating connotations implied by their botanical relatives. Vladimir Dal's fourvolume Dictionary of the Living Russian Language, which Nabokov read during his years as a young émigré poet and student in England, provides multiple botanical implications of "Chernobyl" and "Chernobyl"." 45 Most importantly, Melaleuca, or bottlebrush, incorporates the Greek words melas black and leukos white, and Melaleuca "trees [frequently] have a black trunk and white branches," (Stearn 1972; 1994) thus explaining the Russian term and continuing the black-andwhite motif in the story. ${ }^{46}$

In addition to the black and white implications of Chernobylski, the protagonist's son with the angelic name Mikhail is associated with light and offsets the predominant blackness in the depiction of his mother. Thus, the postcard she has just received from her son represents "the still visible beams of an already extinguished star" (387). But his 


\section{Names 50.1 (March 2002)}

enigmatic nickname for his mother poses a riddle. He calls her "Mulechka" in Russian and "Moolik" in English. Mikhail may want to hint at the harshness of émigré existence by alluding to the Russian verb "múlit'," meaning to rub, grind, chafe, or press to the point of pain. On a more positive note, the Russian noun "Mul'" refers to a nest or den that may reflect the son's longing for home; and, similarly, "mula" as a variant of "mola" refers to a mole at which a ship may cast its anchor. The Russian "mul'ga" and English "mulga" (however, pronounced "malga" with a short "[ $\Lambda]$ "-sound) designate a type of acacia-which would link the nickname to the botanical meanings of Chernobylski. As acacia is derived from the Greek word akis for sharp point, the name could foreshadow the bad news lying in wait for Evgenia Isakovna. However, one type of acacia bears white blossoms and thus fits into Mikhail's role in the story's black-and-white pattern. Another English possibility lies in the words "muliebral" and "muliebrity" which refer to womanliness and typically feminine character traits. This association could render "Moolik" a son's term of endearment for his mother. Also, Mulechka, Moolik, Mother, and Mikhail alliterate, and terms of endearment often derive from a child's early speech development phase and defy logical or scientific scrutiny by outsiders invading the privacy of a family. Consequently, uncertainty remains, and the story does not freeze into the rigidity of a once-and-for-all solved riddle.

\section{Concluding Remarks}

As has become clear, interpreting the names of Nabokov's fictional characters requires the same love of detail as everything else in his works. The reader should be prepared to detect, for instance, puns and irony, anagrams and palindromes, as well as botanical and other meanings which only a dictionary or specific knowledge in literary and scientific matters will reveal. Simultaneously, the reader should cautiously weigh these possible meanings by assessing their integration into the structure of the respective work. Playing with the possibilities of vastly different perspectives, Nabokov's last story, "Lance" (628$38),{ }^{47}$ features an astronaut who travels to an unexplored planet and returns to earth. ${ }^{48}$ The opening sentence of "Lance" serves as both a warning and an invitation to the scrutiny of names, thus indicating the aesthetic pleasure and the possible pitfalls in creation and interpretation: "The name of the planet, presuming it has already received one, is immaterial" (628). Certainly, names are but sounds and printed letters, 
but what does that imply concerning their importance and meaning? Nabokov challenges his reader to tackle these questions anew in each individual case.

\section{Notes}

This essay is an extended version of a paper given at the Annual Convention of the American Name Society in Washington, D.C., on 29 December 2000. I appreciate the questions raised at the conference as well as a suggestion received from Peter Maher, Chicago. Special thanks to Donald Barton Johnson, Santa Barbara, for discussing the entire essay with me.

1. Moderately detailed references to names in Nabokov's stories can be found in Meyer (1993, 7, 9), who discusses the names "Eleonora" in the English version of "Ultima Thule" and Tanya in "An Affair of Honor" in terms of their potential as literary allusions. Connolly $(1993,36)$ raises questions concerning the name "Otto" in "The Fight" as possibly alluding to the sinister quality of Frau Ott in the Russian original of "A Nursery Tale." Kuzmanovich (1993) translates the Russian names in "A Christmas Story" into English. Epstein (1993) interprets the literal meanings of several writers' names and regards the etymology of "Nabokov" (derived from $n a$ boku 'leaning sideways' or 'on one's side' [218]), as part of Nabokov's method of perceiving things from a special angle. Thus everything in his works appears "not straight but refracted like a ray of light at sunset" (218).

Also see my dissertation, Nassim Winnie Berdjis, Imagery in Vladimir Nabokov's Last Russian Novel ( Дap ), Its English Translation (The Gift), and Other Prose Works of the 1930s (1995), especially 151-66. Most recently, and in fascinating depth, Shrayer (1999) insightfully discusses Biblical names in "The Thunderstorm" (23-24), the butterfly name in "Christmas" (35), geographical and personal names in "Terra Incognita" (47), the first name "Vasilij" (164) in several stories, and the name Ferdinand in "Spring in Fialta" (212). His convincing discussion of the name "Chorb" in "The Return of Chorb" (91-98) reveals "three main groups" of "associations" of the name with the devil, with angels (95), and with "Jewish exiles in search of their identity" (96). Equally interesting are his comments on the protagonist's name and on allusions to certain lepidopterists' names in "Pil'gram" / "The Aurelian" (117-21, 128-29). Other works will be mentioned in the context of the stories discussed in this essay.

2. For a discussion of Nabokov as a l'art pour l'art writer see, for example, Stegner (1966); Naumann (1978). Shrayer (1999, 17-19) provides an overview of the discussion on the relationship between ethics and aesthetics in Nabokov's work. Boyd $(1990 ; 1991)$ and Alexandrov (1991) present the most detailed analyses of the metaphysical dimension of the writer's auvre.

3. In Strong Opinions (1973, 33, 40-41), Nabokov confirms that the individual rather than society at large is important in the response to literature; he also describes reading and writing as corresponding pleasures. Just as the writer labors 


\section{Names 50.1 (March 2002)}

to create a work of art, so should the reader invest energy into decoding this work of art (115). Rowe (1971) finds that "The more one reads Nabokov, the more each individual word seems a purposeful participant in the total, uniquely calculated world of his works" (viii).

4. The last anagram is also cited in Strong Opinions (Nabokov 1973, 196).

5. The mixture of female and male elements in the mythical "sirin" recurs in some of the anagrams listed above.

6. Shapiro (1998) devotes an entire chapter to the implications of Nabokov's pen name with its "richness of cultural associations" (10). Significantly, Shapiro illustrates the meanings of "Sirin" not only in ancient Greek and Russian mythology, but also in Russian folk art and Russian literature from the thirteenth through the twentieth centuries.

7. Nabokov's poems also bear witness to the scientist's highly emotional experience of naming a hitherto nameless butterfly and to the strictly earthly context in which such naming happens. In "V Rayu" (1927) / "In Paradise" (Nabokov, 1970), a deceased scientist's soul rejoices in detecting a wonderful specimen, but then realizes the impossibility of bestowing an appellation on "bezymyannye kryla" $(44,1.20) /$ "those unnamable wings" $(45,1.20)$. In "A Discovery" (1943), the persona describes himself as the "godfather to an insect and its first / describer-and I want no other fame" $(155,11.22-23)$. The narrator of the story "Terra Incognita" mentions the natural explorer's sadness at dying before having named all the flora and fauna he first discovered (Nabokov 1995, 299).

8. Johnson and Coates dedicate their monograph Nabokov's Blues: The Scientific Odyssey of a Literary Genius (1999) to these butterflies and their role in the lepidopterist-writer's work. Essays on Nabokov's work as a lepidopterist and selections from his butterfly-related writings constitute Nabokov's Butterflies: Unpublished and Uncollected Writings (Boyd and Pyle 2000). The most recent and most detailed reference work in this context is Zimmer's A Guide to Nabokov's Butterflies and Moths (2001).

9. From the epigraph to "Good Readers and Good Writers" (Nabokov 1980, unnumbered page before 1$)$.

10. In Strong Opinions (1973), Nabokov describes himself as a "dictator" (69) whose fictional "characters are galley slaves" (95). He categorically rejects the notion that fictional characters could possibly develop a dynamic existence of their own by which they would dictate names, behavioral patterns, and plot details to their author.

11. Although Nabokov does not mention that in the interview, "Dolly" also evokes "doll" and thus indicates Humbert Humbert's perspective on Lolita as his plaything.

12. I.e., those included in The Stories of Vladimir Nabokov (1995). The German two-volume edition of Nabokov's stories consists of sixty-six pieces. Dieter E. Zimmer, the editor, mentions the four missing stories (1994, 577), among them 
"Paskhal'nyj dozhd" / "Easter Rain" which had first been published in Russkoe echo on 12 April 1925, a copy of which Svetlana Polsky located after the publication of the Rowohlt volume.

13. "The Wood-Sprite," "Gods," "Beneficence," "The Dragon," "A Letter That Never Reached Russia," "A Guide to Berlin," "Terror," and "The Passenger."

14. "Gods," "Beneficence," "Christmas," "A Letter That Never Reached Russia," "The Return of Chorb," and "Terror."

15. "Gods," "Christmas," "The Return of Chorb," and "Terror."

16. Naumann argues that in "The Return of Chorb," Chorb "never calls her [his recently deceased wife] by name . . . because she is Chorb's blithe spirit" $(1978,26)$.

17. In contrast to this woman's dark colors and her concomitant facelessness (which recalls the unfinished sculpted head of her "wrapped in a wet rag" (74) in the I-narrator's studio), the world around the narrator sports multiple colors ("iridescent" [74], "bronze," "gossamer autumnal blue," "yellow," "russet," "blue," "red," "gray" [75], "green" [77]). The "unkind" woman evoking the narrator's lover wears "a panther coat" (78) which alludes to the both threateningly and enticingly dark colors associated with the other unnamed woman. The warm brown and yellow colors associated with the elderly postcard vendor whom the narrator is watching while waiting for his lover do not only echo the color of coffee with milk which a friendly guard gives to the freezing woman, but also the experience of warmth and of the "blissful bond between me and all of creation" (77) that suddenly overwhelms the narrator. The "little old coffeewoman [sic]" (78) also remains nameless; however, her namelessness represents the narrator's bond with the people and the world around him rather than, as in his lover's case, deceit and aloofness. The narrator implicitly stresses the comparison and contrast between the women by referring to his lover's scent and by then experiencing the elderly woman's enjoyment of the coffee in terms of tasting both: "And a dark, sweet warmth [like brown, hot coffee] poured into my soul [as into the woman's body]. My soul, too, was drinking and heating itself, and the brown little woman tasted of coffee with milk" (77).

18. Nabokov would probably have avoided such a blunt and artistically uninteresting adoption of an actual person's entirely unmodified name.

19. This story first appeared as "Double Talk" in The New Yorker 21.19 (23 June 1945): 20-25.

20. "Greta" (429) and "Schultz" (427) occur twice.

21. Schultz is derived from "Schultheiß" which refers to someone who has police or even military authority (see Pfeifer et al. 1989). Hanks and Hodges (1988) also define "Schultz" as a German "status name for a village headman, from a contracted form of MHG schultheize (OHG sculdheizo). The term originally denoted a man responsible for collecting dues and paying them to the lord of the manor; it is a c[om]p[oun]d of sculd(a) [meaning] debt, [or] due + a deriv. [ative] of heiz(z)an 


\section{Names 50.1 (March 2002)}

[which means] to command." Interestingly, "Schultz" was also adopted as an Ashkenazic name, possibly for "a rabbi, seen as the head of a Jewish community." Unless otherwise noted, all further definitions of the meaning of surnames are taken from Hanks and Hodges (1988).

22. Although both "Schultz" and "Schramm" are also Jewish names, Nabokov obviously focuses on the negative Germanic implications associated with Nazi brutality.

23. The image of "the castle of my life" echoes Nabokov's description of a positively connoted ivory tower: “. . . I should still recommend, not as a writer's prison but merely as a fixed address, the much abused ivory tower, provided of course it has a telephone and an elevator just in case one might like to dash down to buy the evening paper or have a friend come up for a game of chess, the latter being somehow suggested by the form and texture of one's carved abode. It is thus a pleasant and cool place with a grand circular view and plenty of books and lots of useful gadgets" (Nabokov 1980, 371).

24. Hinting at the "disreputable namesake['s]" Nazi sympathies, the narrator describes him as having "a clipped mustache and a crew haircut" (584). The Inarrator gathers this impression when he gets a fleeting glance at his namesake's passport picture during a visit to a French consul who assumed the protagonist was the other man (584). Foreshadowing the party guests' views and possibly even the presentation of music at the event, the protagonist encounters on his way to Mrs. Hall's apartment "An ancient elevator attendant, oddly resembling Richard Wagner" (584), the nineteenth-century composer known for his anti-Semitism whose works were used for propagandistic purposes by the Nazi regime.

25. Again proving Nabokov's expectation that all details must be assessed anew in each work, positively connoted Sybils appear in the story "The Vane Sisters" and the novel Pale Fire.

26. The English name Sybil is derived "from the name . . Sibylla or Sybilla ... of a class of ancient prophetesses inspired by Apollo. According to medieval theology, they were pagans denied the knowledge of Christ but blessed by God with some insight into things to come and accordingly admitted to heaven" (Hanks and Hodges 1990); unless otherwise noted, all subsequent definitions of the meaning of first names are taken from this source. The surname "Hall" is a "topographic name for someone who lived near a large house, or occupational name for someone employed at a hall or manor" (Hanks and Hodges 1988). The name is not only "one of the commonest and most widely distributed of English surnames" (emphasis in the original) but also associated with famous Americans from a signer of the Declaration of Independence (Lyman Hall [1724-1790]) to inventors and scientists.

27. "Sharp English: nickname from ME scharp keen, active, quick . . . " Of course, the reader will think of this implication without consulting a specific name dictionary. 
28. Dr. Shoe's sad gentleness-he corrects people "gently" (587), responds with "a tired smile" and "a touch of sadness in his voice" (588), speaks "in plaintive tones" (589)-merges with the sentimental assertion of his patriotic love for America when he decides to play "The Star-Spangled Banner" on the piano (591). The earlier Wagner reference may aim at recalling that the German composer (rather than an American colleague) was commissioned to write an "American Centennial March" which premiered in Philadelphia in May 1876. This may be construed as analogous to Dr. Shoe's appropriation of an American hymn in praise of liberty.

29. Although "Wehr-" and "Wer-" contrast with regard to vowel length and color in high German, in some German dialects they sound the same.

30. After describing the women as aged and ugly, the narrator ironically remarks: "It is most regrettable that I did not fix the ladies' names in my mind when I was introduced to them" (587).

31. Later on, this description plays a role in the narrator's attempt to fathom whose hat he has accidentally taken.

32. The animal allusion continues with Melnikov's "broken yellow tusk" (587).

33. See Dal' (1880-1882; 1989-1991).

34. For an interpretation of Nabokov's use of characters named Vasiliy Ivanovich, see Shrayer $(1999,157-58,164)$.

35. Using the same image, the writer-protagonist of The Gift imagines himself entering someone else's soul as an exercise in artistic imagination: “. . . he tried as he did everywhere and always to imagine the inner, transparent motion of this or that other person. He would carefully seat himself inside the interlocutor as in an armchair, so that the other's elbows would serve as armrests for him, and his soul would fit snugly into the other's soul-and then the lighting of the world would suddenly change and for a minute he would actually become Alexander Chernyshevski, or Lyubov Markovna, or Vasiliev" (Nabokov 1963, 47-48). Also see Berdjis (1995, 193).

36. A palindromic name already occurs in "The Leonardo" in which Gustav's fiancée is called "Anna." Although Anna does not come across as an aesthetically appealing woman, the potential beauty in the mirror image inherent in her name may be reflected in her naiveté concerning her fiancé's character and her feeble attempts to prevent Romantovski's death.

37. As Johnson has shown, the story "is built entirely on palindromic reversals that mirror the narrative palindrome that is the story's plot" (1979a, 409). On further incorporations of the palindrome's constituent parts into the story see Johnson (1979b).

38. The description of " $t$ " as "gentle" shows the power of directional perception, for " $t$ " is usually the hard (i.e., voiceless) counterpart to soft (i.e., voiced) "d."

39. A phonetic palindrome with a visual flaw occurs in "The Doorbell" (1927) (189-98). The protagonist's mother, whom he dreads meeting after several years, 


\section{Names 50.1 (March 2002)}

lives "care of Babb" (192). "Babb" reflects the short vowel in the Russian spelling of the name, "Бабъ" / "Bab"," and the second "b" replaces-graphically speaking-the 'hard sign' (i.e., "ъ ," transliterated as ",) still used at the end of nouns before the October Revolution and afterwards retained by émigré writers and presses (Vozvrashchenie Chorba [Ann Arbor: Ardis, 1976] 33). In the 1926 story "Razor" (179-82), the title and nickname of the barber-protagonist approximates a palindrome, and his family name, Ivanov, repeats the "a" - "o" alternation.

40. "Frau" indicates the she-devil's German incarnation or at least the national context in which she appears.

41. In the case of "tot," the consonant " $t$ " in the opening and closing positions of the word is anything but gentle and thus contrasts with the t-sounds softened by the "o"'s in "Otto" (see above).

42. Johnson (1979a, 403) also discusses the iconic connection between " $O$ " and the moon in a passage in Nabokov's autobiography Drugie Berega (Conclusive Evidence).

43. Erwin's failure may be the author's punishment for having chosen, in Humbert-fashion, a nymphet-like, Lolita-like fourteen-year-old as lover number twelve (170). Nabokov claims that upon rereading the story decades after its creation he "was eerily startled to meet a somewhat decrepit but unmistakable Humbert escorting his nymphet in the story I wrote almost half a century ago" (644). The man accompanying the young girl "was a famous poet, a senile swan" (170).

44. Vilner is related to the German habitation name "Willner"-which, however, refers to various areas in Germany and Austria.

45. A. chernobyl"': krupnyj vid" polyni [large form of wormwood], Artemisia vulgaris [in English: mugwort, St. John's herb; in German: Mutterkraut, Beifuß, Gänsekraut]; B. Chernobyl': indejskoe derevco [small Indian tree] Melaleuca [in English: cajuput, cajeput; in German: Kajeputbaum, Weißbaum, Myrtenheide]; C. Chernobyl": Sambucus ebulus [in English: dwarf elder, bloodwort, danewort, herbaceous elder, Mediterranean herb-elder; in German: Zwergholunder, Attich]. For the English and German terms, see Wrobel and Creber (1996).

46. Less importantly, yet possibly allowing play with the implications of the bitter pill of bad news, the mugwort (Artemisia vulgaris) and the dwarf elder (Sambucus ebulus) share their association with distilled substances for medicinal or other purposes, as the former yields the flavor for absinthe and the latter provides elderberries for wine.

47. The story first appeared in The New Yorker 27.51 (2 February 1952): 2125.

48. This story, like the earlier ones, invites detailed scrutiny of names. On the most obvious level, the protagonist's name alludes to Lancelot and might thus transform the space explorer into an Arthurian knight in search of the Holy Grail. This observation, however, merely scratches the surface of the story's implications as woven into the names. One would have to discuss the denotative and connotative meanings of all the names and explore their mutual relationship and their participation in the overall interpretation of the work. 


\section{References}

Alexandrov, Vladimir. 1991. Nabokov's Otherworld. Princeton: Princeton Univ. Press.

Berdjis, Nassim Winnie. 1995. Imagery in Vladimir Nabokov's Last Russian Novel (Дар), Its English Translation (The Gift), and Other Prose Works of the 1930s. Mainzer Studien zur Amerikanistik 31. Frankfurt/Main: Peter Lang.

Boyd, Brian. 1990. Vladimir Nabokov: The Russian Years. Princeton: Princeton Univ. Press.

. 1991. Vladimir Nabokov: The American Years. Princeton: Princeton Univ. Press.

Boyd, Brian, and Michael Pyle, eds. 2000. Nabokov's Butterflies:

Unpublished and Uncollected Writings. New translation by Dmitri Nabokov. Boston: Beacon Press.

Connolly, Julian W. 1993. "The Play of Light and Shadow in 'The Fight'." Nicol and Barabtarlo, 25-37.

Dal, Vladimir. 1880-1882, 1989-1991. Tolkovyj slovar' zhivogo velikorusskogo yazyka. [Interpretative Dictionary of the Living Russian Language], 4 volumes. Moskva: Russkij Yazyk.

Epstein, Mikhail. 1993. "Goodbye to Objects, or, the Nabokovian in Nabokov." Nicol and Barabtarlo, 217-24.

Hanks, Patrick, and Flavia Hodges. 1988. A Dictionary of Surnames. New York: Oxford Univ. Press.

. 1990. A Dictionary of First Names. New York: Oxford Univ. Press.

Johnson, D. Barton. 1979a. "Nabokov as a Man of Letters: The Alphabetic Motif in His Work." Modern Fiction Studies 25: 397412.

. 1979b. "A Guide to Nabokov's 'A Guide to Berlin'." Slavic and East European Journal 23: 353-61.

Johnson, Kurt, and Steve Coates. 1999. Nabokov's Blues: The Scientific Odyssey of a Literary Genius. Cambridge, MA: Zoland.

Kuzmanovich, Zoran. 1993. “'A Christmas Story’: A Polemic with Ghosts." Nicol and Barabtarlo, 81-97.

Meyer, Priscilla. 1993. "The German Theme in Nabokov's Work of the 1920s." Nicol and Barabtarlo, 3-14. 
Nabokov, Vladimir. 1963. The Gift. New York: Putnam. . 1973. Strong Opinions. New York: McGraw-Hill. . 1970. Poems and Problems. New York: McGraw-Hill. . 1980. Lectures on Literature. Ed. Fredson Bowers. New York:

Harcourt-Brace-Jovanovich/Bruccoli Clark. . 1995. The Stories of Vladimir Nabokov. New York: Knopf.

Naumann, Marina Turkevich. 1978. Blue Evenings in Berlin: Nabokov's Short Stories of the 1920s. New York: New York Univ. Press.

Nicol, Charles, and Gennady Barabtarlo, eds. 1993. A Small Alpine Form: Studies in Nabokov's Short Fiction. New York: Garland.

Pfeifer, Wolfgang, et al. 1989. Etymologisches Wörterbuch des Deutschen. Berlin: Akademie-Verlag.

Rowe, William Woodin. 1971. Nabokov's Deceptive World. New York: New York Univ. Press.

Shapiro, Gavriel. 1998. Delicate Markers: Subtexts in Vladimir Nabokov's Invitation to a Beheading." New York: Peter Lang.

Shrayer, Maxin S. 1999. The World of Nabokov's Stories. Austin: Univ. of Texas Press.

Stearn, William. 1972, 1994. Stearn's Dictionary of Plant Names for Gardeners: A Handbook on the Origin and Meaning of the Botanical Names of Some Cultivated Plants. London: Cassell.

Stegner, Page. 1966. Escape into Aesthetics: The Art of Vladimir Nabokov. New York: Dial.

Wrobel, Murray, and Geoffrey Creber. 1996. Elsevier's Dictionary of Plant Names in Latin, English, French, German and Italian. Amsterdam: Elsevier.

Zimmer, Dieter E. 1989, 1994. "Zu dieser Ausgabe." Vladimir Nabokov. Erzählungen 2: 1935-1951. Gesammelte Werke 14. Reinbek: Rowohlt. .2001. A Guide to Nabokov's Butterflies and Moths. Hamburg: D.

E. Zimmer. 